\title{
Developing a Bayesian framework for stock assessment and decision analysis of the red sea urchin fishery in Baja California, Mexico
}

\section{Desarrollo de un marco Bayesiano para la valoración del stock y el análisis de decisión de la pesquería del erizo rojo en Baja California, México}

\author{
J Jurado-Molina $^{1}$, JS Palleiro-Nayar ${ }^{2}$, NL Gutiérrez ${ }^{3}$ \\ ${ }^{1}$ Secretariat of the Pacific Community, 95 Promenade Roger Laroque, Anse Vata, New Caledonia. \\ E-mail: jjurado@u.washington.edu \\ ${ }^{2}$ Centro Regional de Investigación Pesquera, Instituto Nacional de la Pesca, Apartado postal 1305, Ensenada, Baja California, \\ México. \\ ${ }^{3}$ School of Aquatic and Fishery Sciences, University of Washington, Box 355020, Seattle, Washington 98195, USA.
}

\begin{abstract}
The red sea urchin (Strongylocentrotus franciscanus) fishery is of importance to the economy of Baja California (Mexico). The commercial fishery started in the early 1970 s as a result of expanding export markets, but has experienced substantial decline in landings and abundance since 1986. Fishery-independent surveys have not been conducted for all fishing areas, thus CPUE and catch data were used to conduct a stock assessment and decision analysis for the red sea urchin stock. The red sea urchin population dynamics was described with the Schaefer biomass dynamic model. Bayesian approaches were used for the estimation of the model parameters and for projecting the population dynamics of the species under different management scenarios, including constant harvest rate and constant catch strategies. This study suggests that the current stock is only $17 \%$ of the virgin stock biomass and that, for a constant catch policy, a 10\% increase in the current catch rate could potentially cause the collapse of the fishery in 20 years. Simulation results suggested that a constant harvest rate between $15 \%$ and $25 \%$ would cause the population to recover and maximize the catch in 2024. Higher harvest rate levels would increase the probability of the biomass being less than $40 \%$ of the population carrying capacity.
\end{abstract}

Key words: constant catch strategy, constant harvest rate, Markov chain Monte Carlo simulations, posterior distribution, Schaefer model.

\section{Resumen}

La pesquería del erizo rojo (Strongylocentrotus franciscanus) es importante para la economía de Baja California (México). Su pesca comercial se inició a principios de los años 70 como resultado de la expansión de su mercado de exportación; sin embargo, se ha detectado una baja sustancial en sus capturas y abundancia desde 1986. Dada la falta de un índice de abundancia relativa independiente de la pesquería para todas las áreas de captura, se utilizaron datos de CPUE y captura para llevar a cabo una valoración del stock del erizo rojo y realizar un análisis de decisión con relación a su pesquería. La dinámica poblacional fue descrita mediante el modelo de biomasa excedente de Schaefer usando métodos Bayesianos para estimar los parámetros del modelo y para proyectar la dinámica poblacional de la especie bajo diferentes escenarios de manejo, los cuales incluyeron estrategias de tasas de explotación constantes y capturas constantes. Los resultados sugieren que el stock actual es sólo 17\% de la bioma virgen y que, para una estrategia de captura constante, un incremento del $10 \%$ en el nivel de captura actual podría causar el colapso de la pesquería en 20 años. Los resultados de las simulaciones sugieren que una estrategia de tasa de explotación constante entre $15 \%$ y $25 \%$ causaría que la población se recuperara y la captura se maximizara en 2024. Mayores niveles de explotación incrementarían la probabilidad de que la biomasa sea menor al $40 \%$ de la capacidad de carga de la población.

Palabras clave: distribución posterior, estrategia de captura constante, Modelo de Schaefer, simulaciones Monte Carlo de cadenas de Markov, tasa de explotación constante.

\section{Introduction}

The red sea urchin (Strongylocentrotus franciscanus) is harvested between Alaska and Baja California. Catch rates have been declining in all management areas (Alaska, British Columbia, Washington, Oregon, California, and Baja California) since the late $1980 \mathrm{~s}$ even though several management

\section{Introducción}

El erizo rojo (Strongylocentrotus franciscanus) se captura desde Alaska hasta Baja California. Las capturas han mermado en todas sus áreas de manejo (Alaska, Columbia Británica, Washington, Oregon, California y Baja California) desde finales de los años 80 a pesar de haberse implementado en 
strategies have been implemented in those regions (Andrew et al. 2002). In British Columbia, the total allowable catch is estimated using deterministic production models (Campbell et al. 1999). In the state of Washington several restrictions were implemented in 1977 including a rotational fishing scheme. Fishing was restricted to winter and a size limit was introduced; however, these restrictions were not enough and the fishery had to be closed in 1988 after the density of legal-sized urchins declined $63 \%$. The fishing season was further restricted and a limited entry scheme reduced the fleet by $67 \%$. In 1993 a model-based quota system was established; managers made ad hoc adjustments to season length based on the observed trends in urchin density and size. In 1994, the Federal District Court granted 16 First Nation tribes access to half the annual sea urchin quota. The most significant result of this decision was the abandoning of the rotational fishing scheme (Andrew et al. 2002). In California, management policies include only restrictive measures such as closed seasons, minimum size, and permit moratorium (Kalvass and Hendrix 1997).

In Baja California, Mexico, the red sea urchin fishery is economically important because it generates a substantial number of jobs (1600 direct and indirect jobs during the 2004-2005 season) and it is an important source of foreign currency. Japan is the primary market for sea urchin gonads with an approximate value of six million dollars. Recreational and subsistence exploitation of red sea urchins started in the late 1960s, but commercial exploitation started in 1972 with an initial annual harvest of $93 \mathrm{t}$ (Palleiro-Nayar et al. 2004). Groups of artisanal fishermen have been granted in exclusivity the fishing area on the west coast of Baja California, from Tijuana to Punta Blanca (fig. 1). Annual catches have fluctuated significantly over the years from 213 to $8493 \mathrm{t}$, increasing from 1972 to 1979 , but decreasing during the following four years

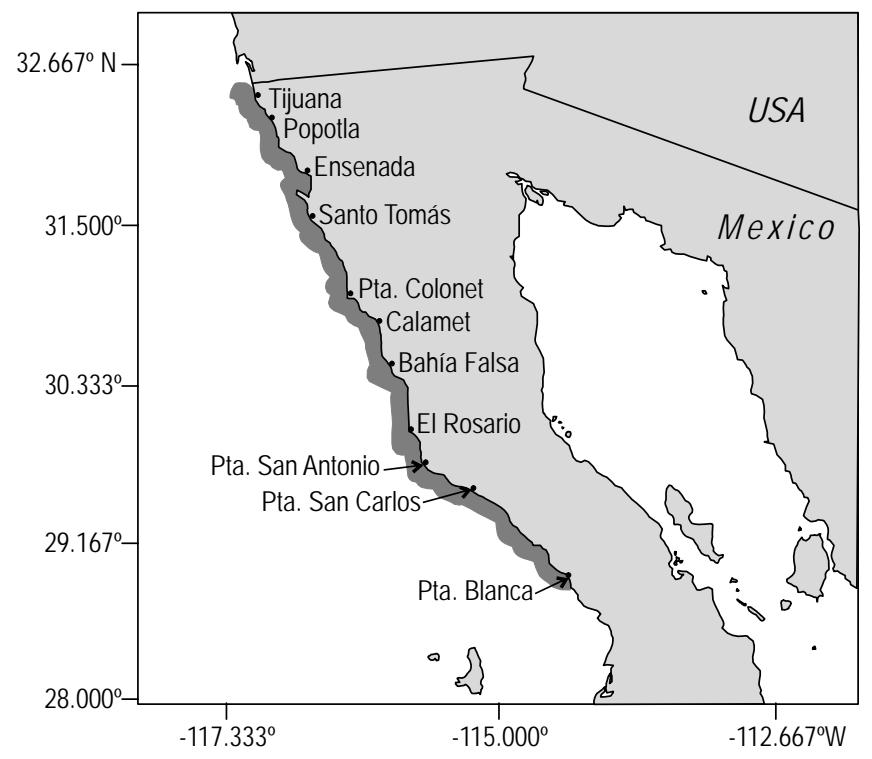

Figure 1. Map of the red sea urchin fishery area in Baja California, Mexico. Figura 1 Mapa de la zona ocupada por la pesquería de erizo rojo en Baja California, México. ellas varias estrategias de manejo (Andrew et al. 2002). En Columbia Británica la captura total permisible se ha estimado con modelos de producción deterministas (Campbell et al. 1999). En el estado de Washington se implementaron varias restricciones en 1977 incluyendo una estrategia rotacional para la pesca restringiéndola al invierno, y se estableció una talla mínima; sin embargo dichas restricciones no fueron suficientes y la pesquería tuvo que ser cerrada en 1988 después de que la densidad de erizos con talla legal cayó $63 \%$. La temporada de pesca se restringió más y se redujo la flota en $67 \%$ mediante un sistema de acceso limitado. En 1993 se estableció un sistema basado en cuotas en el cual las autoridades podían modificar la duración de la temporada con base en las tendencias observadas en la densidad y la talla. En 1994 la Corte Federal de Distrito concedió a 16 tribus indígenas el acceso a la mitad de la cuota anual de erizo. El resultado más notable de esta decisión fue el abandono del sistema rotacional (Andrew et al. 2002). En California, las estrategias de manejo incluyen sólo medidas restrictivas como vedas, talla mínima y moratoria a nuevos permisos (Kalvass y Hendrix 1997).

En Baja California, México, la pesquería del erizo rojo es económicamente importante pues genera un número sustancial de empleos (1600 directos e indirectos durante la temporada 2004-2005) y constituye una fuente importante de divisas. Japón es el principal mercado para la gónada de erizo rojo con un valor aproximado de seis millones de dólares (PalleiroNayar et al. 2004). La explotación de subsistencia y deportiva del erizo rojo inició a finales de los años 60 pero su pesca comercial empezó en 1972 con una captura inicial anual de $93 \mathrm{t}$ (Palleiro-Nayar et al. 2004). La zona de captura en la costa occidental de Baja California, de Tijuana a Punta Blanca (fig. 1), ha sido otorgada en exclusividad a grupos de pescadores rivereños. Las capturas anuales han fluctuado significativamente de 213 a 8493 t, incrementándose entre 1972 y 1979 pero disminuyendo en los siguientes cuatro años debido a los efectos combinados del ENSO 1982-1983 y la intensa presión de pesca (Palleiro-Nayar et al. 1986). Las capturas se incrementaron nuevamente entre 1984 y 1986, alcanzando un máximo en 1986 (8493 t), disminuyendo en los años siguientes, y con un ligero incremento entre 1999 y 2004 (fig. 2). El registro de los datos de CPUE se ha llevado a cabo a partir de 1988. La pesquería del erizo rojo está regulada por la Norma Oficial Mexicana NOM 007-PESC-1993 (Diario Oficial de la Federación, 10 de Agosto de 1993; http:// www.sagarpa.gob.mx/conapesca.) y un comité técnico integrado por representantes de dependencias estatales y federales relacionadas con la pesca, pescadores, e investigadores de la Universidad Autónoma de Baja California (UABC). Las medidas de regulación incluyen una talla mínima del caparazón de $80 \mathrm{~mm}$, buceo autónomo SCUBA como único método de extracción, número de permisos restringido, veda de marzo a junio, y una cuota anual basada en estimaciones llevadas a cabo por el Instituto Nacional de Pesca (INP). El comité técnico de manejo también ha restringido la captura a días entre semana (SEMARNAP 2001). 
because of the combined effect of the 1982-1983 ENSO and heavy fishing pressure (Palleiro-Nayar et al. 1986). Catches increased again between 1984 and 1986, reaching a maximum in 1986 (8493 t), and decreasing in the following years with a slight increase between 1999 and 2004 (fig. 2). CPUE data started to be recorded in 1988. The red sea urchin fishery is regulated by Official Mexican Standard (Norma Oficial Mexicana) NOM 007-PESC-1993 (Diario Oficial de la Federación, 10 de Agosto de 1993; http://www.sagarpa.gob.mx/conapesca.). Harvest tactics include a minimum $80 \mathrm{~mm}$ carapace length, SCUBA diving as the only extraction method, restricted number of permits, a closed fishing season from March to June, and an annual quota based on assessments carried out by the National Institute of Fisheries (INP). In addition, a technical management committee has restricted the harvest to weekdays (SEMARNAP 2001).

Fishery stock assessment and decision analysis should provide the quantitative support needed for managers to make regulatory decisions in the context of uncertainty. This support includes an evaluation of the potential consequences of alternative management actions. An appropriate way of providing quantitative support to managers in the presence of uncertainty is through the use of Bayesian statistical analysis (National Research Council 1998). In this study we explore potential quantitative alternatives for the management of red sea urchin in Baja California, using the Schaefer dynamic biomass model to carry out a stock assessment and a decision analysis based on Bayesian methods that will provide additional information for improving the management of this resource in terms of sustainability .

\section{Material and methods}

We used fisheries-dependent data on commercial landings for the Baja California red sea urchin fishery collected from 1972 to 2004, and CPUE data (kilograms per working day) collected per trip from 1988 to 2004. These data were provided by the Mexican Ministry of Agriculture, Livestock, Rural Development, Fisheries, and Food (SAGARPA), and the Regional Center for Fisheries Research (CRIP) at Ensenada, Baja California. Detailed information on catch, effort, depth, and location fished was found in the divers' harvest logbooks. A biomass dynamic model (Schaefer 1954) was used for the red sea urchin in Baja California:

$$
B_{t+1}=B_{t}+r B_{t}\left(1-\frac{B_{t}}{K}\right)-C_{t}
$$

where $B_{t}$ is the biomass in year $t, r$ is the intrinsic growth rate, $K$ is the carrying capacity, and $C_{t}$ is the commercial catch in year $t$. Due to small catches before 1972, we assumed that the initial population was at its carrying capacity. This model is one of the simplest tools that can be used to characterize the status and productivity of a population. In general, dynamic models have been applied primarily to species with a fairly low

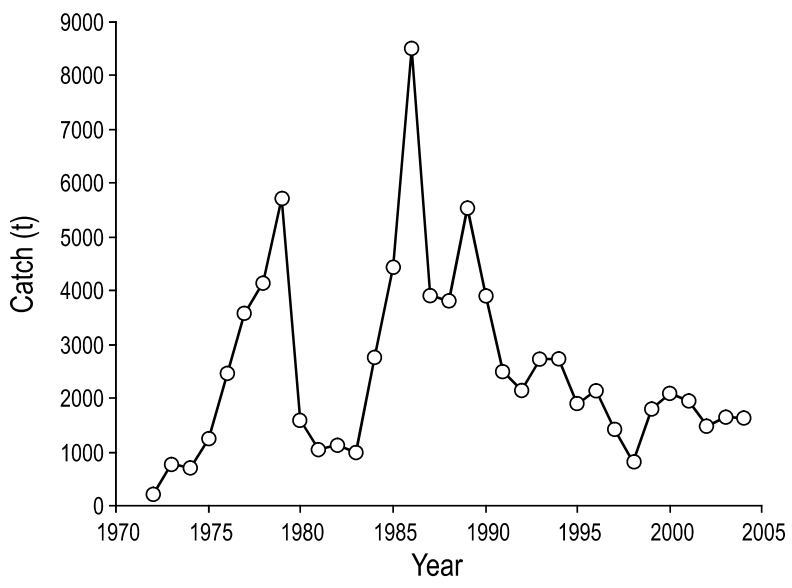

Figure 2 Catches (total weight) of the Baja California red sea urchin fishery.

Figura 2 Capturas (peso total) de la pesquería de erizo rojo en Baja California, México.

La valoración del stock y el análisis de decisión deben aportar los elementos necesarios para que las autoridades pesqueras tomen decisiones regulatorias en un contexto de incertidumbre. Estos elementos deben incluir una evaluación de las potenciales consecuencias de estrategias alternativas de manejo. Una forma de aportar elementos cuantitativos apropiados para la toma de decisiones a las autoridades pesqueras es mediante el uso de la estadística Bayesiana (National Research Council 1998). En este estudio se exploran las posibles alternativas cuantitativas para el manejo del erizo rojo en Baja California, usando el modelo de Schaefer para llevar a cabo una valoración del stock y un análisis de decisión basados en métodos Bayesianos que aportarán información adicional para mejorar el manejo de este recurso en términos de sustentabilidad.

\section{Material y métodos}

Se usaron datos de arribos de la pesquería del erizo rojo en Baja California recabados de 1972 a 2004, y datos de CPUE (kg/día de trabajo) registrados por viaje desde 1988 hasta 2004. Estos datos se obtuvieron de las oficinas de la Secretaria de Agricultura, Ganadería, Desarrollo Rural, Pesca y Alimentación (SAGARPA) y del Centro Regional de Investigación Pesquera (CRIP) en Ensenada, Baja California. En los avisos de arribo de los buzos se detalla información sobre captura, esfuerzo, profundidad y posición geográfica. Se usó un modelo de biomasa excedente (Schaefer 1954) para el erizo rojo de Baja California:

$$
B_{t+1}=B_{t}+r B_{t}\left(1-\frac{B_{t}}{K}\right)-C_{t}
$$

donde $B_{t}$ es la biomasa en el año $t, r$ es la razón intrínseca de crecimiento, $K$ es la capacidad de carga y $C_{t}$ es la captura 
intrinsic growth rate (Punt and Hilborn 1996), as the case of the red sea urchin (SEMARNAP 2001). Model fitting was carried out assuming observation error and a log-normal distribution for CPUE data; therefore, for a given year, the individual negative log-likelihood $L L$ is given by (Hilborn and Mangel 1997):

$$
L L=\ln (\sigma)+\frac{\left(\ln \left(C P U E_{o b s}-\ln C P U E_{e s t}\right)\right)^{2}}{2 \sigma^{2}}
$$

The total negative log-likelihood is the sum of the $n$ components (number of CPUE data available); $\sigma$ is the CPUE standard deviation and it is assumed constant to help reduce the number of estimated parameters from $n+3$ to 4 and make the estimation process possible. CPUE $E_{o b s}$ denotes the observed CPUE data and $C P U E_{\text {est }}$ is calculated as:

$$
C P U E_{\text {est }}=\hat{q} \hat{B}
$$

where $\hat{q}$ is the estimated catchability coefficient and $\hat{B}$ is the estimated biomass. The model parameters, their uncertainty, and the indices of policy performance were estimated using Bayesian methods. This approach provides a simple way to use additional information for building prior distributions of model parameters. In this statistical framework, the probability of the hypothesis given the data or posterior probability distribution $\left(\operatorname{Pr}\left\{H_{i} /\right.\right.$ data $\left.\}\right)$ is estimated with the following equation (Hilborn and Mangel 1997):

$$
\operatorname{Pr}\left\{H_{i} / \text { data }\right\}=\frac{L\left\{\text { data } / H_{i}\right\} \operatorname{Prior}\left\{H_{i}\right\}}{\sum_{j} L\left\{\text { data } / H_{j}\right\} \operatorname{Prior}\left\{H_{j}\right\}}
$$

where $L$ is the likelihood of the data given the hypothesis and Prior is the prior probability distribution of each hypothesis that summarizes all previous knowledge. For the incorporation of prior information, we assumed that the intrinsic growth rate and the carrying capacity have informative log-normal distributed priors. The first prior probability distribution was built based on information from previous estimates of the intrinsic growth rate (0.51) for the red sea urchin (SEMARNAP 2001) and from estimates from the green sea urchin (Strongylocentrotus droebachiensis) reported by Zhang and Perry (2005). The prior probability distribution for the carrying capacity was built based on information from a previous stock assessment for the red sea urchin in Baja California (SEMARNAP 2001). Using informative prior probability distributions allows the incorporation of information available to scientists from the literature and from experiences with other stocks (Punt and Hilborn 1997).

In this study we estimated the posterior probability distribution of the following model parameters: carrying capacity, intrinsic growth rate, catchability, and CPUE standard comercial en el año $t$. Dado lo escaso de las capturas antes de 1972 se supuso que la población inicial correspondía a la capacidad de carga de la pesquería. Este modelo es una de las herramientas más sencillas que se pueden usar para caracterizar el estado y la productividad de una población. En general, se han aplicado modelos dinámicos principalmente a especies con una tasa de crecimiento intrínseco relativamente baja (Punt y Hilborn 1996), como es el caso del erizo rojo (SEMARNAP 2001). El ajuste se llevó a cabo suponiendo errores de observación y que los datos de CPUE tienen una distribución log-normal; por consiguiente, para un año dado el logaritmo negativo de la verosimilitud $L L$ está dado por (Hilborn y Mangel 1997):

$$
L L=\ln (\sigma)+\frac{\left(\ln \left(C P U E_{o b s}-\ln C P U E_{e s t}\right)\right)^{2}}{2 \sigma^{2}}
$$

El logaritmo negativo total de la verosimilitud es la suma de la $n$ componentes (número de datos de CPUE disponibles), $\sigma$ es la desviación estándar del CPUE y se supone constante para ayudar a reducir el número de parámetros de $n+3$ a 4 y así hacer posible el proceso de estimación. $C P U E_{\text {obs }}$ denota los

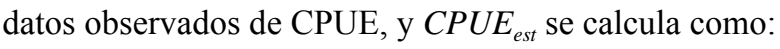

$$
C P U E_{\text {est }}=\hat{q} \hat{B}
$$

donde $\hat{q}$ es el coeficiente de capturabilidad estimado y $\hat{B}$ es la biomasa estimada. Los parámetros del modelo, su incertidumbre y los indicadores de desempeño de la estrategia de manejo, se estimaron con métodos Bayesianos. Estos métodos permiten usar de una forma sencilla información adicional para construir las distribuciones a priori de los parámetros del modelo. En este marco estadístico, la probabilidad de la hipótesis dados los datos o distribución de probabilidad posterior $\operatorname{Pr}\left\{H_{i} /\right.$ data $\}$ es estimada con la siguiente ecuación (Hilborn y Mangel 1997):

$$
\operatorname{Pr}\left\{H_{i} / \text { data }\right\}=\frac{L\left\{\text { data } / H_{i}\right\} \operatorname{Prior}\left\{H_{i}\right\}}{\sum_{j} L\left\{\text { data } / H_{j}\right\} \operatorname{Prior}\left\{H_{j}\right\}}
$$

donde $L$ es la verosimilitud de los datos dada la hipótesis y Prior es la distribución de probabilidad a priori de cada hipótesis que resume todo el conocimiento previo. Para la incorporación de la información a priori se supuso que la tasa intrín-seca de crecimiento y la capacidad de carga tienen distribuciones a priori informativas y log-normales. La primera distribución a priori se construyó con base en información de estimaciones previas de la tasa intrínseca de crecimiento (0.51) para el erizo rojo (SEMARNAP 2001), y de estimaciones para el erizo verde Strongylocentrotus droebachiensis (Zhang y Perry 2005). La distribución de probabilidad a priori para la capacidad de carga se construyó basada en información de una 
deviation. We also estimated posterior probability distributions for the indices of policy performance (current stock biomass in 2004 and depletion of the stock in 2004). The posterior probability distributions of parameters and indices of policy performance were estimated using Markov chain Monte Carlo (MCMC) simulations. A total of 30 million runs were done using AD Model Builder (Fournier 1996, Otter Research Ltd.) with a "burn-in" of 1000 parameter vectors. Every 60th sample was saved to test convergence by the Geweke (Geweke 1992), Heidelberger and Welch (Heidelberger and Welch 1983), and autocorrelation tests from CODA (Convergence Diagnosis and Output Analysis Software for Gibbs sampling outputs, version 4.0) for the statistical package R (R Foundation for Statistical Computing, ISBN 3-900051-07-0).

For the decision analysis, the model was projected for 20 years considering two different management scenarios. In the first scenario, a range of constant harvest rates from $10 \%$ to $40 \%$ by $5 \%$ intervals was used. In the second scenario, for comparisons and simulations of the stock dynamics under the current level of fishing mortality, a reference catch (average catch from 2002 to 2004) was defined, and further simulations were carried out using percentages (70-110\%) of this reference catch.

The indexes of policy performance used to assess each management option were the probability of the population being less than $40 \%$ of the carrying capacity and the red sea urchin catch in 2024. The first indicator provides information on the stock's reproductive capacity and the second measures the outputs from the fishery. Although more indicators could be used, these two indicators can measure the basic expected performance of the red sea urchin fishery system. Results were summarized in decision tables.

\section{Results}

Results from the MCMC runs showed that the model fit the observed CPUE data well (fig. 3). The estimated carrying capacity of the red sea urchin was $24,465 \mathrm{t}$ with a $95 \%$ probability interval of $(20,830,28,964)$. The estimate of the intrinsic growth rate was 0.48 with a $95 \%$ probability interval of $(0.38,0.63)$. The estimate of the catchability coefficient was 0.027 with a $95 \%$ probability interval of $(0.021,0.035)$. The estimate of the CPUE standard deviation used in the likelihood was 0.17 with a $95 \%$ probability interval of $(0.13,0.24)$. There was a high negative correlation between $K$ and $r(-0.99), q$ and $K(-0.97)$ and $r(-0.97)$. The CPUE standard deviation was not correlated with any parameter. The posterior probability distributions of the intrinsic growth rate (fig. 4a) and the carrying capacity (fig. 4b) did not fully coincide with their corresponding prior probability distributions. As shown in figure 5, the estimated stock biomass decreased greatly over the 1970s and 1980 s, with a maximum value at the beginning of the fishery in $1972(24,465$ t) and a minimum in 1997 (3452 t). From 1995 to 2004 the biomass remained stable at low levels (fig. 5). The most probable value of the biomass in 2004 was $4247 \mathrm{t}$ (fig. 5) valoración del stock previa (SEMARNAP 2001). El uso de distribuciones de probabilidad a priori permite que los científicos incorporen información disponible en la literatura y su experiencia en otras investigaciones a la valoración del stock (Punt y Hilborn 1997).

En este trabajo se estimó la distribución a posteriori de los siguientes parámetros del modelo: capacidad de carga, tasa intrínseca de crecimiento, y la capturabilidad y desviación estándar de la CPUE. También se estimaron las distribuciones a posteriori de los indicadores de desempeño de la estrategia de manejo (biomasa del stock en 2004 y la reducción porcentual del stock en 2004). La distribución de probabilidad de parámetros e indicadores fueron estimados usando simulaciones Monte Carlo de cadenas de Markov (MCMC). Se hizo un total de 30 millones de corridas usando el modelador $\mathrm{AD}$ (Fournier 1996, Otter Research Ltd.) con un "quemado" de 1000 vectores de pará-metros. Se guardó una de cada sesenta muestras para probar la convergencia mediante pruebas de Geweke (Geweke 1992), Heildenberg y Welch (Heildenberg y Welch 1983) y autocorrelación del paquete CODA (Convergence Diagnosis and Output Analysis Software for Gibbs sampling outputs version 4.0), para el paquete estadístico $\mathrm{R}$ (The $\mathrm{R}$ Foundation for Statiscal Computing ISBN 3-900051-07-0).

Para el análisis de decisión, el modelo se proyectó a 20 años considerando dos escenarios distintos de manejo: en el primer escenario se usó un rango de tasas de explotación constantes de $10 \%$ a $40 \%$ en intervalos de $5 \%$; en el segundo escenario, para comparaciones y simulaciones de la dinámica del stock bajo el actual nivel de mortalidad por pesca, se definió una captura de referencia (promedio de capturas entre 2002 y 2004), y se realizaron más simulaciones usando porcentajes $(70 \%$ a $110 \%)$ de esta captura de referencia.

Los índicadores de desempeño para valorar cada opción de manejo fueron la probabilidad de que la población sea menor a $40 \%$ de su capacidad de carga y la captura de erizo rojo en 2024. El primer indicador da información sobre la capacidad reproductiva y el segundo mide la información importante para la pesquería. A pesar de que se pueden usar otros indicadores, estos dos pueden medir el desarrollo esperado de la pesquería de erizo rojo. Los resultados se resumieron en las tablas de decisión.

\section{Resultados}

Los resultados de las simulaciones MCMC mostraron que el modelo se ajusta bien a los datos observados de CPUE (fig. 3). La capacidad de carga estimada del erizo rojo en Baja California fue de 24,465 $t$ con un intervalo de probabilidad de $95 \%$ de $(20,830,28,964)$. La estimación de la tasa intrínseca de crecimiento fue de 0.48 con un intervalo de probabilidad de $95 \%$ de $(0.38,0.63)$. La estimación de la capturabilidad $q$ fue de 0.027 con un intervalo de probabilidad de $95 \%$ de $(0.021$, 0.035). Asimismo, la estimación de la desviación estándar de la CPUE usada en la verosimilitud fue de 0.17 , con un 


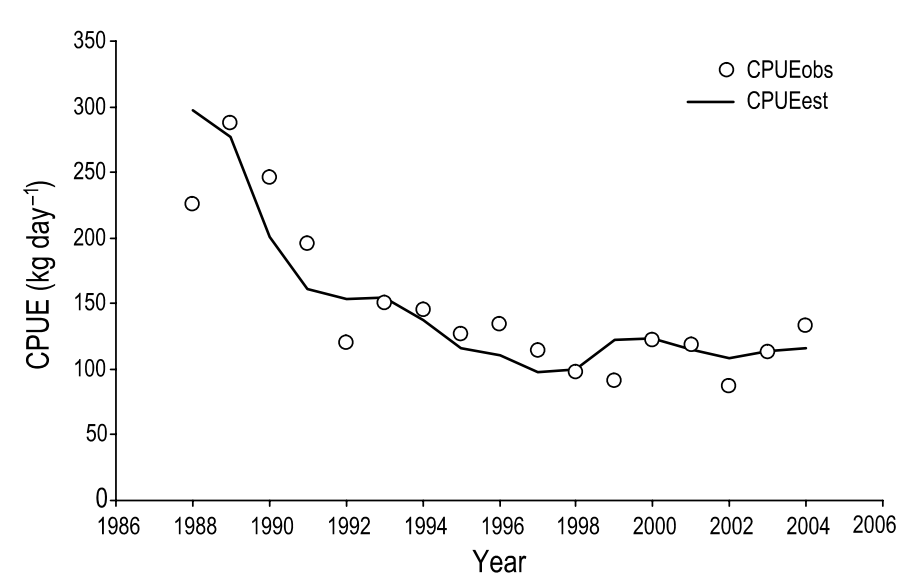

Figure 3. Schaefer model MCMC fit for the Baja California red sea urchin CPUE data.

Figura 3. Ajuste por MCMC del modelo de Schaefer a los datos de CPUE para el erizo rojo de Baja California.

with a $95 \%$ probability interval of $(2827,6054)$, representing an increment of $23 \%$ compared with the minimum value in 1997. Results also confirm the high depletion levels of the biomass in 2004, suggesting that there is only $17 \%$ of the carrying capacity with a $95 \%$ probability interval of $(0.12,0.25)$ and that there is a probability of $80 \%$ of the depletion being less or equal to 0.2 .

Regarding the convergence tests, the $P$ values of the $\mathrm{Z}$ score in the Geweke convergence diagnostic were all greater than 0.05 , indicating no evidence against convergence. The Heidelberger and Welch halfwidth and stationary tests indicated that all parameters had passed both tests. In general, results from these tests suggest that the number of iterations $(30,000,000)$ for the MCMC sampler was sufficient for convergence.

Regarding the MCMC projections for the future dynamics of the red sea urchin in Baja California, the most probable biomass trajectories from 2004 to 2024 for the constant catch and constant harvest management strategies are shown in figure $6(\mathrm{a}, \mathrm{b})$. For the constant harvest strategy the biomass increases for all the rate levels except $35 \%$ and $40 \%$, which produced a decreasing trend in the future biomass (fig. 6a). In the case of the constant catch strategy, all percentages of the reference catch produced an increase in biomass; however, when we simulated a constant catch strategy greater than $110 \%$ of the reference catch the population crashed.

Concerning the decision analysis (tables 1-3), for the simulations including a constant harvest rate strategy, the results suggested that a $25 \%$ harvest rate could produce an expected $16 \%$ probability that the biomass will be less than $40 \%$ of the carrying capacity in 20 years. A 30\% harvest rate would increase this probability to $54 \%$ (table 1). Smaller harvest rates produced negligible probabilities. When the catch in 2024 was used as index of policy performance, the lowest expected catch (1939 t) corresponded to a harvest rate of 40\%. A similar low expected catch (1985 t) was found for a 10\% harvest rate. The intervalo de probabilidad de $(0.13,0.24)$. Hubo una fuerte correlación negativa entre $K$ y $r(-0.99)$, $q$ у $K(-0.97)$, y $r$ $(-0.97)$. La desviación estándar de la CPUE no se correlacionó con los demás parámetros. La distribuciones a posteriori de la tasa intrínseca de crecimiento (fig. 4a) y de la capacidad de carga (fig. 4b) no coincidieron con sus distribuciones a priori. Como se observa en la figura 5, la biomasa estimada disminuyó de manera importante en los años setenta y ochenta, con un valor máximo al inicio de la pesquería en 1972 (24,465 t) y un mínimo en 1997 (3452 t). A partir de 1995 y hasta 2004, la biomasa permaneció estable a niveles bajos (fig. 5). El valor más probable de la biomasa en 2004 fue de $4247 \mathrm{t}$ (fig. 5), con un intervalo de $95 \%$ de probabilidad de $(2827,6054)$, y representó un incremento de $23 \%$ con respecto a su valor mínimo en 1997. Los resultados también confirman los altos niveles de reducción de la biomasa en 2004 sugiriendo que sólo hay 17\% de la capacidad de carga con un intervalo del $95 \%$ de probabilidad de $(0.12,0.25)$ y que hay una probabilidad de $80 \%$ de que la disminución sea menor o igual a $20 \%$.

En lo que respecta a las pruebas de convergencia, los valores de probabilidad $p$ para $Z$ en el diagnóstico de convergencia de Geweke fueron todos mayores a 0.05 , lo que indica que no

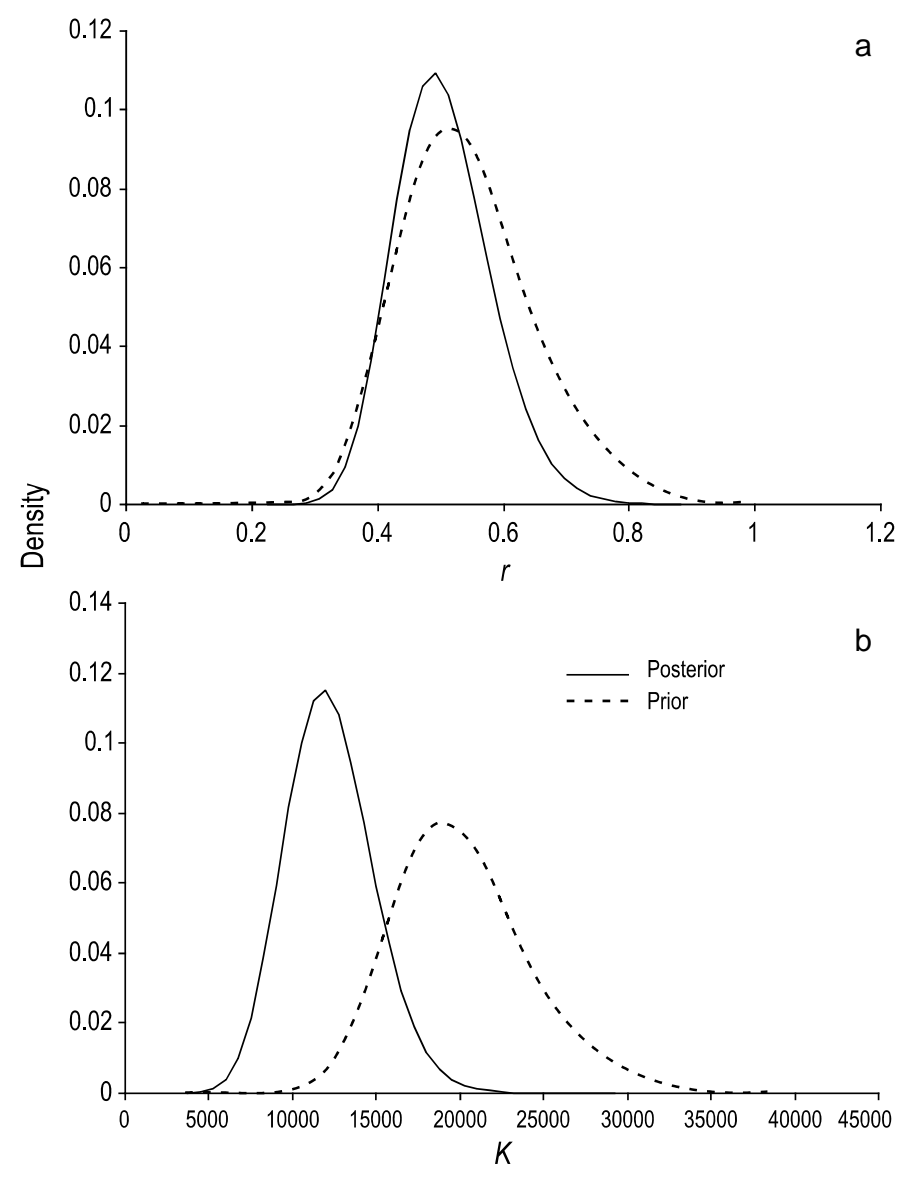

Figure 4. Comparison of the posterior and prior probability distributions of (a) intrinsic growth rate and (b) carrying capacity.

Figura 4. Comparación de las distribuciones de probabilidad a posteriori y a priori de (a) la tasa de crecimiento intrínseca y (b) la capacidad de carga. 


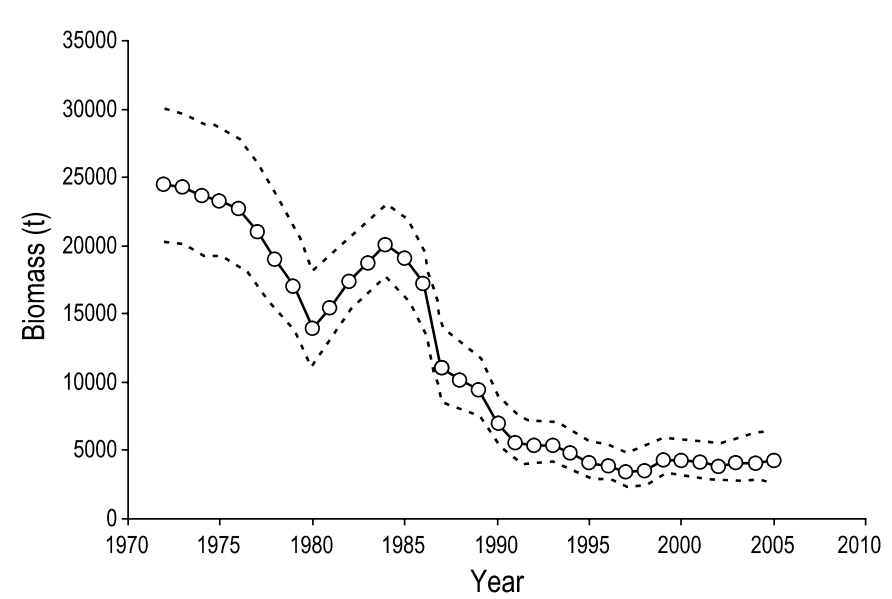

Figure 5. Time series of the red sea urchin biomass estimates with their 95\% probability interval (dotted lines) for Baja California from 1972 to 2004. Figura 5. Series de tiempo de los estimados de biomasa de erizo rojo de 1972 a 2004 en Baja California con su intervalo de pobabilidad del 95\% (líneas punteadas).

highest expected catch value (2987 t) corresponded to the $25 \%$ harvest rate (table 2). The use of the constant catch strategy in the simulations showed different results (table 3). The results from the simulations suggested that the probability of the biomass being less than $40 \%$ is less than $10 \%$ for all percentages of the reference catch options. The highest probability (8\%) corresponded to $110 \%$ of the reference catch. However, it is important to point out that the simulation of harvesting more than $110 \%$ of the reference catch caused the population to collapse.

\section{Discussion}

The current red sea urchin fishery management tools, based on restrictive measures, have been partially effective as they have resulted in a non-decreasing trend starting in 1999; however, these measures may not be sufficient to achieve the
Table 1 Decision analysis for the Baja California red sea urchin fishery estimated with a constant harvest rate strategy and the probability of the biomass being less than $40 \%$ of the carrying capacity in 2024 as index of policy performance. The probabilities for three levels of biomass in 2004 are shown: low biomass (0.25), medium biomass $(0.50)$, and high biomass (0.25). These values were used to calculate the expected value of the performance indicator.

Tabla 1 Análisis de decisión para la pesquería del erizo rojo en Baja California aplicando una estrategia de tasa de explotación constante, y probabilidad de que la biomasa resulte menor que $40 \%$ de la capacidad de carga en 2024 como indicador del desempeño de esta estrategia. Se muestran las probabilidades para tres niveles de biomasa en 2004: poca biomasa (0.25), biomasa media (0.50), y mucha biomasa (0.75). Se utilizaron estos valores para calcular el valor esperado del indicador de desempeño.

\begin{tabular}{cllll}
\hline & Low & Medium & High & Expected \\
\hline H rate & 0.25 & 0.50 & 0.25 & \\
$10 \%$ & 0.000 & 0.000 & 0.000 & 0.000 \\
$15 \%$ & 0.000 & 0.000 & 0.000 & 0.000 \\
$20 \%$ & 0.002 & 0.005 & 0.028 & 0.010 \\
$25 \%$ & 0.048 & 0.131 & 0.320 & 0.158 \\
$30 \%$ & 0.308 & 0.545 & 0.772 & 0.543 \\
$35 \%$ & 0.706 & 0.884 & 0.963 & 0.859 \\
$40 \%$ & 0.931 & 0.985 & 0.996 & 0.974 \\
\hline
\end{tabular}

hay evidencias contra la convergencia. Todos los parámetros pasaron las pruebas de la mitad de ancho de banda de Heidelberger y Welch y las pruebas estacionarias. En general, los resultados de estas pruebas sugirieron que el número de iteraciones $(30,000,000)$ para las simulaciones MCMC fue suficiente para satisfacer el criterio de convergencia.

En lo que respecta a las proyecciones MCMC para la dinámica poblacional futura del erizo rojo en Baja California, las trayectorias más probables de 2004 a 2024 para una estrategia de capturas y tasas de explotación constantes se muestran en la figura $6(a, b)$. Como se observa, con una estrategia de

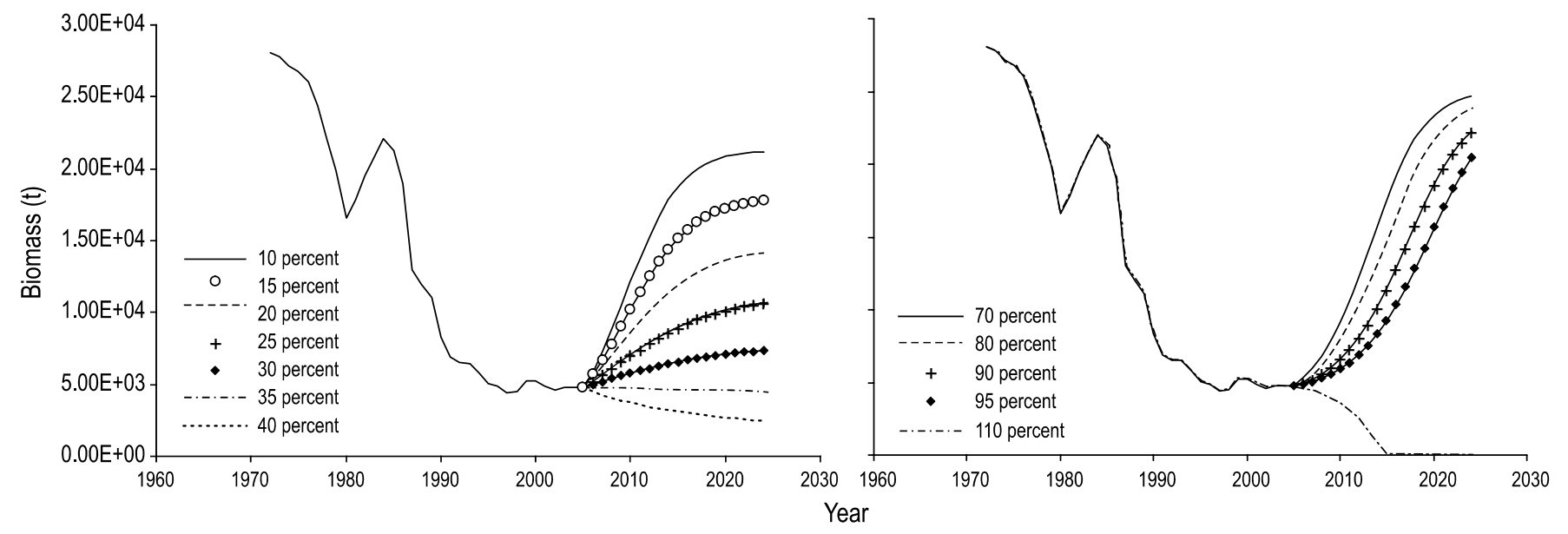

Figure 6. MCMC model projections for the red sea urchin biomass under two management strategies: (a) constant harvest rate and (b) constant catch. Figura 6. Proyecciones del modelo MCMC para la biomasa erizo rojo bajo dos estartegias de manejo: (a) tasa de explotación constante y (b) captura constante. 
Table 2. Decision analysis for the Baja California red sea urchin fishery estimated with a constant harvest rate strategy and the catch (t) in 2024 as index of policy performance. The probabilities for three levels of biomass in 2004 are shown: low biomass (0.25), medium biomass (0.50), and high biomass (0.25). These values were used to calculate the expected value of the performance indicator.

Tabla 2. Análisis de decisión para la pesquería del erizo rojo en Baja California aplicando una estrategia de tasa de explotación constante, y la captura (t) en 2024 como indicador del desempeño de esta estrategia. Se muestran las probabilidades para tres niveles de biomasa en 2004: poca biomasa (0.25), biomasa media (0.50), y mucha biomasa (0.75). Se utilizaron estos valores para calcular el valor esperado del indicador de desempeño.

\begin{tabular}{ccccc}
\hline & Low & Medium & High & Expected \\
\hline H rate & 0.25 & 0.50 & 0.75 & \\
$10 \%$ & 1915 & 1986 & 2055 & 1985 \\
$15 \%$ & 2538 & 2589 & 2624 & 2585 \\
$20 \%$ & 2934 & 2927 & 2884 & 2918 \\
$25 \%$ & 3098 & 3001 & 2848 & 2987 \\
$30 \%$ & 3034 & 2826 & 2555 & 2810 \\
$35 \%$ & 2762 & 2447 & 2084 & 2435 \\
$40 \%$ & 2331 & 1939 & 1541 & 1938 \\
\hline
\end{tabular}

proposed goal of reaching a $50 \%$ level of the virgin biomass (SEMARNAP 2001). We therefore recommend exploring different approaches and, in particular, we suggest a quantitative approach for establishing a management plan that assures a sustainable fishery. This study represents a first step in achieving this goal.

Regarding the high parameter correlation, in practice there is ussually severe parameter confounding among the three parameters of the Schaefer model, $r, K$, and $q$. Their estimation requires the availability of historical variation in stock size and fishing pressure (Hilborn and Walters 1992). For the red sea urchin, there is a lack of contrast in CPUE and catch data because they were collected when the fishing pressure was already high. A management plan that proposes decreasing the fishing pressure on this resource will provide the opportunity of improving the contrast of the CPUE data, allowing a better estimate of the Schaefer parameters.

The MCMC estimate of the intrinsic growth rate found in this study is not significantly different from the value previously reported by SEMARNAP (2001), who suggested an $r$ value of 0.56 with a $95 \%$ confidence interval $(0.4,0.8)$. As shown, results suggested that the catch and CPUE data contain enough information; the prior distribution lost its influence in the estimation of the posterior probability distribution of the carrying capacity. This is less obvious in the posterior probability distribution of the intrinsic growth rate.

Results imply that the biomass level in 2004 is low, suggesting that the population could be depleted. Although biomass estimates have been stable in recent years, our findings and those of a previous study (SEMARNAP 2001) indicate that the resource abundance is less than $20 \%$ of the virgin biomass. It is important to point out that $20 \%$ of the virgin
Table 3. Analysis of decision for the Baja California red sea urchin fishery estimated with a constant catch strategy and the probability of biomass being less than $40 \%$ of the carrying capacity in 2024 as index of policy performance. The probabilities for three levels of biomass in 2004 are shown: low biomass (0.25), medium biomass (0.50), and high biomass (0.25). These values were used to calculate the expected value of the performance indicator.

Tabla 3. Análisis de decisión para la pesquería del erizo rojo en Baja California aplicando una estrategia de captura constante, y probabilidad de que la biomasa resulte menor que 40\% de la capacidad de carga en 2024 como indicador del desempeño de esta estrategia. Se muestran las probabilidades para tres niveles de biomasa en 2004: poca biomasa (0.25), biomasa media (0.50), y mucha biomasa (0.75). Se utilizaron estos valores para calcular el valor esperado del indicador de desempeño.

\begin{tabular}{ccccc}
\hline & Low & Medium & High & Expected \\
\hline H rate & 0.25 & 0.50 & 0.75 & \\
$70 \%$ & 0.00 & 0.00 & 0.00 & 0.00 \\
$75 \%$ & 0.01 & 0.00 & 0.00 & 0.00 \\
$80 \%$ & 0.01 & 0.00 & 0.00 & 0.01 \\
$85 \%$ & 0.02 & 0.01 & 0.00 & 0.01 \\
$90 \%$ & 0.03 & 0.02 & 0.00 & 0.02 \\
$95 \%$ & 0.03 & 0.02 & 0.01 & 0.03 \\
$100 \%$ & 0.03 & 0.04 & 0.02 & 0.04 \\
$105 \%$ & 0.05 & 0.05 & 0.03 & 0.06 \\
$110 \%$ & 0.05 & 0.06 & 0.05 & 0.08 \\
\hline
\end{tabular}

tasa de explotación constante la biomasa se incrementa para todas los tasas de explotación, excepto para las de 35\% y $40 \%$ que produjeron una tendencia decreciente en la biomasa futura (fig. 6a). En el caso de una estrategia de captura constante, todos los porcentajes de la captura de referencia produjeron un incremento en la biomasa. Sin embargo, cuando se simulo una estrategia de captura constante mayor a $110 \%$ de la captura de referencia la población se colapsó.

En cuanto al análisis de decisión (tablas 1-3), para las simulaciones que incluyeron una estrategia de tasa de explotación constante los resultados sugieren que una tasa del $25 \%$ podría producir una probabilidad de $16 \%$ de que la biomasa sea menor que $40 \%$ de la capacidad de carga en veinte años. Una tasa del 30\% incrementaría esta probabilidad a $54 \%$ (tabla 1 ). Al usar tasas de explotación menores las probabilidades resultaron muy pequeñas. Cuando se usó la captura en 2024 como indicador de desempeño de la estrategia de manejo la menor captura esperada (1939 t) correspondió a una tasa de explotación de $40 \%$. Para una tasa de $10 \%$ se encontró algo similar (1985 t). La mayor captura esperada (2987 t) correspondió a la tasa de $25 \%$ (tabla 2). El uso de una estrategia de captura constante en las simulaciones mostró resultados distintos (tabla 3). Los resultados de las simulaciones sugieren que la probabilidad de que la biomasa sea menor que $40 \%$ es menor que $10 \%$ para todos los porcentajes de la captura de referencia. La mayor probabilidad ( $8 \%$ ) correspondió a un $110 \%$ de la captura de referencia. Sin embargo, es importante señalar que la simulación de una captura mayor a $110 \%$ de la captura de referencia causó que la población se colapsara súbitamente. 
biomass is a level that is not considered conservative, but represents an inferior limit where low levels of recruitment could be observed (Beddington and Cooke 1983). Therefore, it is necessary to explore different scenarios to distinguish the potential options for the rebuilding of the red sea urchin stock and avoid a potential closure of the fishery due to a stock collapse in the near future.

The MCMC simulations with constant catch strategy suggested that continuing the exploitation of the red sea urchin at a slightly higher level than the current one (reference catch) could cause the red sea urchin population to collapse in 20 years. This information is important due to the lack of quota limits for this fishery. Currently, this resource is managed with restrictions in the number of permits, size limit, and seasonal closures. These measures may not be enough to warrant that the annual catch would be smaller than $100 \%$ of the reference catch; therefore, a different approach is necessary to help rebuild this resource and avoid the collapse of the population.

In general, policy options with the highest yields also have the highest risks of stock depletion. Fishery managers must thus choose a policy that has the highest expected benefits but also acceptably low risks (McAllister and Kirkwood 1998). Our simulation results suggested that a harvest rate between $15 \%$ and $25 \%$ would cause the population to recover and maximize the catch in 2024. A strategy of $30 \%$ would also produce a high catch in 2024; however, it would increase the probability of the biomass being less than $40 \%$ of the carrying capacity to $54 \%$. Constant harvest rate is the policy that potentially has the highest benefits and acceptable low risks. It is well known that constant catch strategies are prone to catastrophic failure because under natural variation, the stock is bound to get low enough so that the quota looms larger than the factor of change, driving the stock down faster as the number of remaining fish declines (Walters and Martell 2004). This might be the case of the current situation for the red sea urchin, where the biomass and the landings have decreased to a low level that might threaten the fishery in the medium or long term. A rebuilding plan is necessary but it cannot be based on the current strategies. Therefore, a constant harvest rate strategy would be strongly recommended for the recovery of this resource. Unfortunately some problems will arise along with this strategy. The adoption of a constant harvest strategy will require establishing a systematic program sampling to obtain biomass estimates independent of the fishery for improving the current estimation process. The estimation process is currently based on CPUE data. This is not an optimal choice because this indicator can increase even during stock declines due to contractions in the range area used by the individuals (Walters and Martell 2004). This might be the case of the red sea urchin because of its benthic nature. A potential opposition of fishermen to this policy would arise due to the reduction in the levels of allowable catch. An adoption of a $25 \%$ harvest strategy would reduce the catch in the short term. Hence, it is also necessary to assess the economical impacts of this measure in relation to loss of income and jobs.

\section{Discusión}

Las medidas de regulación aplicadas actualmente a la pesquería del erizo rojo en Baja California son de tipo restrictivo, han resultado parcialmente exitosas pues la pesquería no ha mostrado una tendencia decreciente a partir de 1999. Sin embargo, tales medidas podrían ser insuficientes para alcanzar la meta propuesta de llegar a un 50\% del nivel de la biomasa virgen (SEMARNAP 2001). Por lo anterior es recomendable explorar otras estrategias de manejo; en particular, en este trabajo se sugiere un enfoque cuantitativo para establecer un plan de manejo que asegure la sustentabilidad del recurso. Este trabajo representa un primer paso en esa dirección.

En cuanto a la fuerte correlación entre parámetros, en la práctica usualmente existe mucha confusión estadística entre los tres parámetros del modelo de Schaefer, $r, K$ y q. Su estimación requiere disponer de variaciones históricas en la magnitud del stock y la presión de pesca (Hilborn y Walters 1992). En el caso del erizo rojo no hay contraste en los datos de CPUE y captura ya que éstos se recabaron cuando la presión de pesca ya era alta. Un plan de pesca que proponga disminuir la presión de pesca sobre este recurso daría la oportunidad de incrementar el contraste en los datos de CPUE, permitiendo mejores estimaciones de los parámetros del modelo de Schaefer.

La estimación de la tasa intrínseca de crecimiento con el método MCMC no es significativamente diferente del valor reportado previamente por SEMARNAP (2001), la cual ha sugerido un valor de $r$ de 0.56 con un intervalo de confianza del $95 \%(0.4,0.8)$. Como se muestra, los resultados sugieren que los datos de captura y CPUE contienen suficiente información; la distribución a priori perdió su influencia en la estimación de la distribución de la capacidad de carga a posteriori. Esto es menos obvio en la distribución de la tasa intrínseca de crecimiento a posteriori.

Los resultados implican que el nivel de biomasa en 2004 es bajo, lo que sugiere que la población pudiera estar sobre explotada. A pesar de que las estimaciones de biomasa han sido estables en los últimos años, los resultados de este trabajo y de trabajos previos (SEMARNAP 2001) establecen que la abundancia es menor al $20 \%$ de la biomasa virgen. Es importante señalar que un nivel de $20 \%$ no se considera conservador, sino que representa un límite inferior en el que se pueden observar niveles bajos de reclutamiento (Beddington y Cooke 1983); por ello es necesario explorar distintos escenarios para distinguir las posibles alternativas para la reconstrucción del stock del erizo rojo y evitar la potencial veda permanente de la pesquería debido al colapso del stock en un futuro cercano.

Las simulaciones MCMC con una estrategia de captura constante sugieren que si se explota el erizo rojo en un nivel ligeramente mayor que la captura de referencia, la población podría colapsar en veinte años. Esta información es importante debido a la ausencia de cuotas en la pesquería. Actualmente este recurso se maneja mediante un número de permisos restringido, talla mínima y vedas. Estas medidas podrían no ser suficientes para garantizar que la captura anual pudiera ser 
In addition to harvest rates, one must also account for the ecological factors that may influence the dynamics and recovery of the red sea urchin population. These include the influence of oceanographic patterns on recruitment; food availability; predation by sea stars (Pycnopodia helantoides, Patiria miniata), lobsters (Panulirus interruptus), and crabs (Cancer spp.); and the competition for space and food with the purple sea urchin (Strongylocentrotus purpuratus). The purple sea urchin is caught commercially in small quantities (300 t); thus, there has been an expansion in its bathymetric distribution to a depth of $25 \mathrm{~m}$, partially occupying the ecological niche of the red sea urchin (Palleiro-Nayar et al. 2004, Ramírez-Félix 2001). These factors may adversely offset the recovery of the red sea urchin.

Unfortunately, single-species models, such as the Schaefer model, cannot account for these more complex scenarios. Other methods such as multispecies (Sparre 1991, JuradoMolina et al. 2005) or ecosystem models (Christensen and Walters 2004) are needed to include these interactions.

This study is part of an effort to incorporate quantitative methods in the management of the red sea urchin fishery. It is necessary, however, to explore other single-species models (e.g., size-structured or individual based models), or multispecies and ecosystem models. In the future, new relative indexes of abundance independent of the fishery, biological information, and environmental variables will be included in the stock assessment and help to explore different scenarios in the red sea urchin fishery management.

Although some stock assessments have been made, Mexican fishery managers have not taken full advantage of the decision analysis and quantitative methods. This study is a first step in that direction. Another option for applying this methodology is the red octopus (Octopus maya) from the Yucatan Peninsula, where this methodology could be applied successfully due to the availability of biomass estimates independent of the fisheries (J Jurado-Molina, pers. comm.). We hope our study provides new information to scientists, industry, and fishery managers to help improve the management of the red sea urchin in Baja California.

\section{Acknowledgements}

We wish to thank J Ianelli (Alaska Fisheries Science Center) and A Punt (University of Washington) for their support and suggestions regarding this work. This publication was partially funded by the Joint Institute for the Study of the Atmosphere and Ocean (JISAO), under NOAA Cooperative Agreement No. NA17RJ1232 (Contribution \# 1358).

\section{References}

Andrew NL, Agastuna Y, Ballesteros E, Baxhin AG, Creaser EP, Barnes DKA, Botsford LW, Bradbury A, Campbell A, Dixon JD, Einarsson S, Gerring P, Hebert K, Hunter M, Hurt SB, Johnson CR, Juinio-Menez MA, Kalvass P, Miller RJ, Moreno CA, Palleiro JS, Rivas D, Robinson SML, Schroeter SC, Stenek RS, menor al $100 \%$ de la captura de referencia; por consiguiente es necesario un método distinto que ayude a reconstruir el recurso evitando su colapso.

En general, las alternativas de manejo con mayores rendimientos son también tienen las más riesgosas en cuanto al colapso de la población; por lo tanto, las autoridades pesqueras deben seleccionar la estrategia de manejo que rinda los mayores beneficios a un nivel de riesgo aceptable (McAllister y Kirkwood 1998). Los resultados de las simulaciones sugieren que una tasa de explotación entre $15 \%$ y $25 \%$ podría permitir que la población se recupere y que la captura se maximice en 2024. Una estrategia del $30 \%$ también produciría una captura alta en 2024, sin embargo, incrementaría la probabilidad de que la población fuera menor al $40 \%$ de la capacidad de carga en un $54 \%$. La tasa de explotación constante es la estrategia que potencialmente rendiría los mayores beneficios y niveles de riesgo aceptables. Se sabe que las estrategias de captura constante pueden fallar de manera catastrófica debido a que, por su variación natural el stock puede caer a niveles suficientemente bajos de tal forma que la cuota pueda llegar a ser mayor que el factor de cambio, disminuyendo el stock mas rápidamente (Walters y Martell 2004). Esta podría ser la situación actual del erizo rojo, en la que la biomasa y las capturas han disminuido a un nivel tan bajo que podrían estar amenazando la pesquería a mediano y largo plazo. Se requiere un plan para su reconstrucción; por lo tanto, para la recuperación de este recurso es ampliamente recomendable una estrategia de tasa de explotación constante. Desafortunadamente con esta estrategia seguramente surgirán algunos problemas. La adopción de una estrategia de tasa de explotación constante requerirá el establecimiento de un programa sistemático de muestreo para obtener estimaciones de biomasa independientes de la pesquería que permitan mejorar el proceso de estimación actual. Actualmente el proceso de estimación está basado en datos de CPUE, lo cual no es óptimo porque este indicador puede incrementarse aún cuando el stock disminuya debido a contracciones en el área ocupada por los individuos (Walters y Martell 2004). Debido a su naturaleza béntica, este podría ser el caso del erizo rojo. Podría surgir oposición de los pescadores a adoptar esta estrategia dada la reducción inminente de los niveles de captura permisible. La adopción de una estrategia de $25 \%$ reduciría la captura en el corto plazo, por lo que se hace necesario valorar también los impactos económicos de esta medida con respecto a la pérdida de ingresos y empleos de la población.

Además de las tasas de explotación se deben tomar en cuenta los factores ecológicos que podrían influir en la dinámica y la recuperación de las poblaciones de erizo rojo. Éstos incluyen la influencia de los patrones oceanográficos en el reclutamiento y la disponibilidad de alimento, la depredación por estrellas de mar (Pycnopodia helantoides, Patiria miniata), langostas (Panulirus interruptus) y cangrejos (Cancer spp.), y la competencia por espacio y alimento con el erizo morado (Strongylocentrotus purpuratus). El erizo morado es capturado comercialmente sólo a pequeña escala (300 t), por lo que ha 
Vadas RI, Woodby DA, and Xiaoqu Z. 2002. Status and management of world sea urchin fisheries. Oceanogr. Mar. Biol. 40: $343-425$.

Beddington JR, Cooke JG. 1983. The potential yield of fish stocks. FAO Fish. Tech. Pap. 242: 47 pp.

Campbell A, Boutillier J, Rogers J. 1999. Discussion on a precautionary approach for management of the red sea urchin fishery in British Columbia. Canadian Stock Assessment Secretariat Research Document 99/094, 156 pp.

Christensen V, Walters CJ. 2004. Ecopath with ecosim: Methods, capabilities and limitations. Ecol. Model. 172: 109-139.

Fournier D. 1996. An introduction to AD MODEL BUILDER for use in nonlinear modeling and statistics. Otter Research Ltd.

Geweke J. 1992. Evaluating the accuracy of sampling-based approaches to the calculation of posterior moments. In: Berger JO, Bernardo JM, Dawid AP, Smith AFM (eds.), Bayesian Statistics 4: Proceedings of the Fourth Valencia International Meeting. Clarendon Press, Oxford, pp. 169-193.

Heidelberger P, Welch P. 1983. Simulation run length control in the presence of an initial transient. Oper. Res. 31: 1109-1144.

Hilborn R, Walters CJ. 1992. Quantitative Fisheries Stock Assessment: Choice, Dynamics and Uncertainty. Chapman \& Hall, London, 570 pp.

Hilborn R, Mangel M. 1997. The Ecological Detective: Confronting Models with Data. Princeton Univ. Press, Princeton, New Jersey, $315 \mathrm{pp}$.

Jurado-Molina J, Livingston PA, Ianelli JN. 2005. Incorporating predation interactions to a statistical catch-at-age model for a predator-prey system in the eastern Bering Sea. Can. J. Fish. Aquat. Sci. 62: 1865-1873.

Kalvass PE, Hendrix JM. 1997. The California red sea urchin Strongylocentrotus franciscanus fishery: catch, effort and management trend. Mar. Fish. Rev. 59: 21-17.

McAllister MK, Kirwood GP. 1998. Bayesian stock assessment: A review and example application using the logistic model. ICES J. Mar. Sci. 55: 1031-1060.

National Research Council. 1998. Improving Fish Stock Assessments. National Academy Press, Washington, DC, 177 pp.

Palleiro-Nayar JS, Lelevier AG, Navarrete M, Romero JM. 1986. Análisis y medidas de regulación de erizo rojo Strongylocentrotus franciscanus en Baja California, México. CRIP Ensenada. Informe Técnico del Instituto Nacional de la Pesca, 54 pp.

Palleiro-Nayar JS, Salgado-Rogel MA, Aguilar-Montero D, RomeroMartínez M, Martínez-García FJ. 2004. Análisis de la pesquería del erizo rojo Strongylocentrotus franciscanus en la costa noroccidental de Baja California, México. INPESCA Vol. 1: $67 \mathrm{pp}$.

Punt AE, Hilborn R. 1996. Biomass Dynamics Models. User's Manual. FAO Computerized Information Series (Fisheries), No. 10. FAO, Rome, $62 \mathrm{pp}$.

Punt AE, Hilborn R. 1997. Fisheries stock assessment and decision analysis: The Bayesian approach. Rev. Fish Biol. Fisher. 10: 50-60.

Ramírez-Félix E. 2001. Análisis de la extracción de erizo rojo de mar (Strongylocentrotus franciscanus, A Agassiz 1863) de acuerdo a especie clave y conectividad, en el área de Santo Tomás a Punta China, Baja California. Rev. Cienc. Pesq. (INP) No. 14: 19-22.

Schaefer MB. 1954. Some aspects of the dynamics of populations important to the management of commercial marine fisheries. Inter-Am. Trop. Tuna Comm. Bull. 1: 25-56.

SEMARNAP. 2001. Sustentabilidad y pesca responsable en México: Evaluación y manejo 1999-2000. Http://cripens.inp.gob.mx/ sust_pesc_resp_ev_manejo_1999_2000. expandido su distribución batimétrica a una profundidad de 25 $\mathrm{m}$ ocupando parcialmente el nicho ecológico del erizo rojo (Palleiro-Nayar et al. 2004, Ramírez 2001). Todos estos factores podrían afectar de forma adversa la recuperación del erizo rojo.

Desafortunadamente los modelos monoespecíficos como el de Schaefer no pueden tomar en cuenta este tipo de escenarios que son más complejos. Para incluir estas posibles interacciones se requiere del uso de otros métodos como los modelos multiespecíficos (Sparre 1991, Jurado-Molina et al. 2005) o modelos ecosistémicos (Christensen y Walters 2004).

Este trabajo es parte de un esfuerzo para incorporar métodos cuantitativos al manejo de la pesquería del erizo rojo. Sin embargo, es necesario explorar otros modelos monoespecíficos (con estructura de tallas o modelos basados en individuos), o multiespecíficos y ecosistémicos. En el futuro se incluirán nuevos indicadores relativos de abundancia independientes de la pesquería, información biológica y variables ambientales en la valoración del stock, lo que ayudará a explorar distintos escenarios para el manejo de esta pesquería.

A pesar de que se han realizado valoraciones del stock, las autoridades pesqueras mexicanas no han aprovechado plenamente el uso de los análisis de decisión y los métodos cuantitativos. Este trabajo es un primer paso en esta dirección. Otra pesquería en la que se podría aplicar esta metodología es la del pulpo rojo (Octopus maya) en la Península de Yucatán, en la cual su aplicación podría resultar exitosa debido a la disponibilidad de estimaciones de biomasa independientes de la pesquería (J Jurado-Molina, comunicación personal). Los autores esperan que este trabajo aporte nueva información a los científicos, la industria y las autoridades pesqueras, para mejorar el manejo de la pesquería del erizo rojo en Baja California.

\section{Agradecimientos}

Agradecemos a J Ianelli (Alaska Fisheries Science Center) y A Punt (University of Washington) por su apoyo y sugerencias respecto a este trabajo. Esta publicación fue parcialmente financiada por el Joint Institute for the Study of the Atmosphere and Ocean (JISAO) bajo el acuerdo cooperativo NOAA No NA17RJ1232, contribución \# 1358.

Sparre P. 1991. Introduction to multispecies virtual population analysis. ICES Mar. Sci. Symp. 193: 12-21.

Walters C, Martell SJD. 2004. Fisheries Ecology and Management. Princeton Univ. Press, Princeton, New Jersey, 399 pp.

Zhang Z, Perry RI. 2005. Use of the state-space modeling with Bayesian approach to estimate target reference points for green sea urchin (Strongylocentrotus droebachiensis) stocks in the Queen Charlot Strait region, British Columbia, Canada. Fish. Res. 74: 253-264.

Recibido en enero de 2009; aceptado en mayo de 2009. 